\title{
Effect of Azotobacter and Pseudomonas with Mineral Fertilizer on Yield and Yield Components of Malt Barley (Hordeum vulgare L.)
}

\author{
Amare Tadesse* Kasu Tadesse Wondesen Melak \\ Ethiopian Institute of Agricultural Research, Kulumsa Agricultural Research Center, \\ P.O.Box 489 Assela, Ethiopia
}

\begin{abstract}
The effect bio-fertilizer composed of Azotobacter and Pseudomonas spp. was investigated on yield and yield components of malt barley (H. vulgar L). The treatments which were laid at Bekoji, a potential malt barley district in the southeastern highlands of Ethiopia, Azotobacter + Pseudomonas + 46/20.2 N/P kg ha -1, Pseudomonas $+46 / 20.2 \mathrm{~N} / \mathrm{P} \mathrm{kg}$ ha $-1,46 / 20.2 \mathrm{~N} / \mathrm{P} \mathrm{kg}$ ha -1 , Azotobacter +46/20.2 N/P kg ha -1 , Azotobacter + Pseudomonas, Azotobacter, Pseudomonas, C- (uninoculated and unfertilized) in randomized complete block design(RCBD) with three replications. Results indicated that application of the bio-fertilizer treatments alone resulted in the minimum performance of different agronomic parameters studied, while inorganic fertilizer application with dual inoculation with Azotobacter + Pseudomonas gives the highest and significant effect on grain yield, harvest index, biological yield, plant height, and thousand seed weight as compared to other treatments. But this trend was not observed in the number of spikes for that case the result was reversed. Hence, the study showed that the use of chemical fertilizer along with dual inoculation (Azotobacter + Pseudomonas) should be considered as a component of inputs especially in inorganic farming systems of malt barley production.
\end{abstract}

Keywords: Malt barley, Azotobacter, Pseudomonas, Bio-fertilizer.

DOI: $10.7176 / \mathrm{JNSR} / 12-11-04$

Publication date:June $30^{\text {th }} 2021$

\section{INTRODUCTION}

Malt barley (Hordeum vulgar L.) is a major income source to smallholder farmers in the highland areas of Ethiopia, particularly where the agro-ecologies are not more productive than other cereal crops (MoA (Ministry of Agriculture), 2018). However, in Ethiopia, barley productivity (2.66 t/ha) is lower compared to that of other barleyproducing countries such as the United Arab Emirates, Belgium, and the Netherlands where mean productivities are 8.0, 7.6, and 7.0 t/ha, respectively) (FAOSTAT, 2018). This is due to the combination of genetic, socioeconomic constraints and inappropriate use of integrated technologies. Besides, malt barley requires optimum environmental factors such as altitude, rainfall, and soil $\mathrm{pH}$ which range between 2,300 and 3,000 masl, 500 and $1,000 \mathrm{~mm}$ and 5.5 and 6.5, respectively. Prefer soil types well-drained light brown and red soil) due to the quality standards of beer factories (Ferede M. et al., 2020).

Nowadays the practice of boosting yield by inorganic fertilizer is conventional but the impact on long-term soil health and productivity is not promising, so using environmentally friendly soil microbes is gaining momentum. Moreover, intensive cultivation due to population growth has seriously depleted the macro and micronutrients in our soil (Getachew A. and Tilahun A., 2017). A part of rhizospheric bacteria is considered plant growth-promoting bacteria (PGPB) due to their positive effect on plant growth and development. Plant growthpromoting bacteria based on their metabolic activity can be grouped into biofertilizers, phytostimulants, or biopesticides. These efficient bacteria due to various direct or indirect effects exerted on plants have a crucial role in agricultural sustainability. Recently were reported diverse genera as PGPB like Acetobacter, Achromobacter, Arthrobacter, Azoarcus, Azospirillum, Azotobacter, Bacillus, Burkholderia, Frankia, Phyllobacterium, Pseudomonas, Serratia, and Rhizobium (Ashok K and Vijay SM, 2019). Bacterial strains have different plant growth-promoting (PGP) activities like multi-stress resistances (temperature, $\mathrm{pH}$, salinity) and other properties such as cellulose, phytin, and lecithin degradation, alkaline phosphatase, and alkaline protease activity, and siderophore production. Plant growth-promoting rhizobia (PGPR) can produce hormones that stimulate plant growth, make nutrients available, fix atmospheric nitrogen, act as bio-control agents, and improve soil structure and Carboxylic acid production, decreasing $\mathrm{pH}$ and bound calcium and other nutrient availability (Ashok $\mathrm{K}$ and Vijay SM, 2019).

Thus, inoculation of plants with these PGPR is accompanied by a significant increase in productivity that results from two main beneficial mechanisms: stimulation of plant growth and protection of plants against soilborne diseases (Saida A et al., 2015) and could allow growers to reduce the use of synthetic fertilizers and increase the sustainability of crop production. Strains that possessed traits associated with PGPR have been observed to increase the shoot length, root length, and fresh and dry weight of plants in the growth chamber study. Similarly, under the pot trial, maximum crop traits were observed under a single or different consortium. This confirms that 
this consortium could provide growers with a sustainable approach to reduce synthetic fertilizer usage in wheat production (AS et al., 2019; Ashok K and Vijay SM, 2019; Satyanarayana T and Johri BN, 2012; Sayyed RZ et al., 2019).

In Ethiopia, only a few studies on tef root-associated microorganisms have been undertaken. Accordingly, the effects of PGPR on growth and yield of tef were evaluated by Delelegn W. and Fassil A (2011). Microbial inoculum of two Bacillus species (Bacillus megatherium and Bacillus mucilaginous) improved the growth of the plant as well as the nutritional assimilation of the plant (Saida A et al., 2015). However, information on little has been known about the use of bio-fertilizers on malt barley in our soils, and hence, the present study was undertaken to generate information on the effects of phosphate solubilizing and nitrogen-fixing microorganisms (Azotobacter sp. and Pseudomonas sp.) on yield and yield components of malt barley.

\section{MATERIALS AND METHODS}

2.1. Description of the Study Area

The study area, Bekoji, is found in the Arsi zone of Oromia Regional State in the southeastern part of Ethiopia. It is located at an altitude of $2780 \mathrm{~m}$.a.s.l. with a latitude of $7^{\circ} 32^{\prime} \mathrm{N}$ and a longitude of $39^{\circ} 15^{\prime} \mathrm{E}$. The area has a longterm mean annual precipitation of $1020 \mathrm{~mm}$ and a mean maximum and minimum temperature of $18.6^{\circ} \mathrm{C}$ and $7.9^{\circ} \mathrm{C}$, respectively. The soil texture of the research site is reddish clay with a $\mathrm{pH}$ of 5.4.

\subsection{Experimental Design and Treatments,}

Field trials were laid out in randomized complete block designs (RCBD) with three replications. The treatments comprised Azotobacter + Pseudomonas + 46/20.2 N/P kg ha -1; Pseudomonas +46/20.2 N/P kg ha -1; 46/20.2 N/P $\mathrm{kg}$ ha -1 ; Azotobacter + 46/20.2 N/P kg ha -1; Azotobacter + Pseudomonas; Azotobacter; Pseudomonas; C(negative control) which is uninoculated and unfertilized.

\subsection{Planting and Agronomic Practices}

Field experiments were carried out in the three successive years of growing seasons at Bekoji, in the Arsi zone where barley production has high potential. The experimental plot size was $10.4 \mathrm{~m} 2$ which is $2.6 \mathrm{~m} \times 4 \mathrm{~m} \times 13$ rows of $20 \mathrm{~cm}$ apart. The space between each plot was $50 \mathrm{~cm}$. Di-ammonium phosphate (DAP) containing phosphorus and nitrogen at a ratio of $18 \mathrm{~N}: 46 \mathrm{P}$ was used as a source of inorganic fertilizer. malt barley variety (cv. Holker) was sown at a seed rate of $150 \mathrm{~kg}$ ha- 1 . To inoculate with biological fertilizers, the seeds were first sterilized with $70 \%$ ethanol for two minutes and cleaned five times with distilled water, and were mixed with a sugar solution to serve as a sticker. Then the seeds were inoculated with the powder of Pseudomonas and Azotobacter at a rate of $500 \mathrm{~g}$ ha-1. The bacteria were applied with a carrier of fine lignite powder capable of passing through 75-106 $\mu \mathrm{m}$ sieves. The inoculants contain a minimum of 108 (at manufacturing date) up to107 (15 days before the expiry date) of viable cells. The Barley seeds were sown on the experimental plots soon after inoculation with the bio-fertilizers. All agronomic practices were carried out as recommended for the area. At harvest, the data recorded were plant height $(\mathrm{cm})$, number of grain per spike, 1000-grain weight $(\mathrm{g})$, biological yield ( $\mathrm{kg}$ ha-1), harvest index (grain yield/biological yield $\times 100)$, grain yield $(\mathrm{kg}$ ha-1). Data were analyzed with Proc GLM procedure, SAS Tukey Honest Significant Difference (HSD) test was used to separate treatment means at a probability level of 0.05 (SAS, 2009).

\section{RESULTS AND DISCUSSION}

\subsection{Number of Spikes}

The combined analysis of variance over three years indicated that the number of spikes per $\mathrm{m} 2$ was significantly $(\mathrm{p}<0.05)$ and positively influenced by inorganic fertilizer application and bio-fertilizer inoculation (Table 3). The highest number of spikes per $\mathrm{m} 2$ was obtained from the application of Pseudomonas $+46 / 20.2 \mathrm{~kg} \mathrm{NP}$ ha- 1 . The number of spikes per $\mathrm{m} 2$ was increased by integrating bio-fertilizer with chemical fertilizer. Application of Pseudomonas $+46 / 20.2 \mathrm{~kg}$ NP ha-1 increased the number of spikes per $\mathrm{m} 2$ by $28.6 \%$ and $33.1 \%$ compared to the control and Azotobacter alone, respectively. Inoculation of seeds with the bio-fertilizer (Pseudomonas or Azotobacter) treatment along with the application of chemical NP fertilizer increased the number of spikes per $\mathrm{m} 2$ by $24.2 \%$ to $28.6 \%$ compared to non-inoculated plants (Table 3 ). These results were consistent with previous findings (Abedi et al., 2010; Kandil et al., 2011; Liu and Shi, 2013).

\subsection{Plant Height}

Plant height was significantly $(\mathrm{p}<0.05)$ and positively affected by nitrogen, phosphorus, and bio-fertilizer application as shown in Table 3 . The highest plant height $(109.2 \mathrm{~cm})$ was obtained from the addition of dual inoculants (Azotobacter + Pseudomonas) with inorganic fertilizer +46/20.2 NP kg ha -1). The next good treatments (Pseudomonas + 46/20.2 NP; NP alone and Azotobacter +NP) were not significantly different from the top performer. The 5th treatment (Azotobacter + pseudomonas) had an intermediate plant height $(96.7 \mathrm{~cm}) \mathrm{which}$ is 
significantly lower than the four top performances. The last three treatments including negative control did not much to plant height increase (Table 3). Previous studies have also reported similar findings (Zorita and Canigia, 2009; Daneshmand et al., 2012; Namvar et al., 2012; Liu and Shi, 2013).

\subsection{Grain Yield}

Analysis of variance for individual and combined years showed that the mean grain yield of malt barley was significantly $(\mathrm{p}<0.05)$ affected by applying bio-fertilizers (Table 2$)$. The highest $(3686.0 \mathrm{~kg}$ ha-1) and lowest (1924 kg h-1) grain yields were obtained by applying dual bio-fertilizer inoculants along with NP fertilizer, and from the control, respectively. This showed a remarkable $91.6 \%$ of yield increase (Table 2). The inoculants (Azotobacter and Pseudomonas) are effective only when combined with NP fertilizers. Comparing Pseudomonas $+\mathrm{NP}$ and Azotobacter +NP treatments, the first is significantly better than the latter in increasing both grain and biomass yields (Table 2). The combination of the two inoculants along with inorganic NP resulted in superior grain and biomass yield increments. Similar results were reported on the effects of N fertilizer (Kizilkaya, 2008; Wortman et al., 2011; Scursoni et al., 2012; Getachew et al., 2014) and bio-fertilizer (Saini et al., 2004; Sary et al., 2009; Namvar et al., 2012) on grain yield of different crops. The increase in grain yield in the inoculated plants could be attributable to the exudation of plant growth regulators (PGRs), such as auxins, gibberellin, and cytokinin by Azotobacter sp., in addition to the increase in nutrient availability (Vessey, 2003). Piccinin et al. (2013) showed that the combined application of chemical NP fertilizers and bio-fertilizer inoculation improved the grain yield of malt barley. Generally, nano bio-fertilizer application increased crop growth and improved yield and yield components in barley (Seyed M. et al., 2013) and extended the growing period in wheat (Mahmoud M. et al., 2014).

\subsection{Biomass Yield}

Results revealed that treatment effects for either biofertilizers or uninoculated were significant for both grain yield and total biomass yields of malt barley for each year (Table 1). In the combined analysis, application of Azotobacter + Pseudomonas + 46/20.2 N/P kg ha-1 increased total biomass by $35.8 \%$, compared to the Azotobacter treatments alone, and 50.1\% increase to sole Pseudomonas inoculation similarly, Azotobacter + Pseudomonas inoculated plants with NP fertilizer resulted in higher total biomass $(9388 \mathrm{~kg}$ ha -1$)$ than the control with $5469 \mathrm{~kg}$ ha-1.

Table 1. The effect of inorganic and growth-promoting microorganisms on grain yield and biomass in Barley for three years

\begin{tabular}{|c|c|c|c|c|c|c|}
\hline \multirow{2}{*}{ Treatments } & \multicolumn{2}{|c|}{ Year 1} & \multicolumn{2}{|c|}{ Year 2} & \multicolumn{2}{|c|}{ Year 3} \\
\hline & $\mathrm{GY}\left(\mathrm{kg} \mathrm{ha}^{-1}\right)$ & $\mathrm{BY}\left(\mathrm{kg} \mathrm{ha}^{-1}\right)$ & $\mathrm{GY}\left(\mathrm{kg} \mathrm{ha}^{-1}\right)$ & $\mathrm{BY}\left(\mathrm{kg} \mathrm{ha}^{-1}\right)$ & GY(kg ha-1) & $\mathrm{BY}\left(\mathrm{kg} \mathrm{ha}^{-1}\right)$ \\
\hline Azotobacter + Pseudomonas +46/20.2 N/P kg ha ${ }^{-1}$ & $3867.72 \mathrm{a}$ & $9797.31 \mathrm{a}$ & $3582.62 \mathrm{a}$ & $8796.69 \mathrm{a}$ & $3607.31 \mathrm{a}$ & $9570.48 \mathrm{a}$ \\
\hline Pseudomonas $+46 / 20.2 \mathrm{~N} / \mathrm{P} \mathrm{kg} \mathrm{ha}^{-1}$ & $3581.04 \mathrm{a}$ & $8345.33 \mathrm{ab}$ & $3166.28 b$ & $9644.38 \mathrm{a}$ & $3195.96 b$ & $9191.00 \mathrm{ab}$ \\
\hline $46 / 20.2 \mathrm{~N} / \mathrm{P} \mathrm{kg} \mathrm{ha}^{-1}$ & $3118.23 b$ & $7870.69 \mathrm{bc}$ & $2944.72 b c$ & $9326.02 \mathrm{a}$ & $3249.24 \mathrm{ab}$ & $9170.33 \mathrm{ab}$ \\
\hline Azotobacter $+46 / 20.2 \mathrm{~N} / \mathrm{P} \mathrm{kg} \mathrm{ha}^{-1}$ & $2928.51 b$ & $7512.54 \mathrm{bcd}$ & $2699.71 \mathrm{~cd}$ & $6530.03 b$ & $2957.18 b c$ & $7715.50 \mathrm{bcd}$ \\
\hline Azotobacter + Pseudomonas & $2401.39 \mathrm{c}$ & $8746.51 \mathrm{ab}$ & $2391.69 \mathrm{de}$ & $6256.95 b$ & $2871.41 \mathrm{bc}$ & $8272.45 \mathrm{abc}$ \\
\hline Azotobacter & $2304.82 \mathrm{c}$ & $6662.64 \mathrm{~cd}$ & $2203.94 \mathrm{e}$ & $6273.65 b$ & $2590.22 \mathrm{~cd}$ & $7202.80 \mathrm{~cd}$ \\
\hline Pseudomonas & $2125.66 \mathrm{~cd}$ & $6293.78 d$ & $2118.07 \mathrm{ef}$ & $5774.81 \mathrm{~b}$ & $2241.82 d$ & $6697.42 \mathrm{~cd}$ \\
\hline$-\mathrm{C}$ (negative control) & $1757.41 \mathrm{~d}$ & $4697.55 \mathrm{e}$ & $1825.36 \mathrm{f}$ & $5678.24 \mathrm{~b}$ & $2189.98 \mathrm{~d}$ & $6029.92 d$ \\
\hline MEAN & 2760.60 & 7490.79 & 2616.55 & 7285.10 & 2862.89 & 7981.24 \\
\hline $\mathrm{CV}$ & 8.87 & 11.84 & 7.62 & 17.36 & 8.02 & 12.06 \\
\hline LSD & 428.69 & 1553.75 & 349.06 & 2215.00 & 402.30 & 1686.17 \\
\hline
\end{tabular}

Bio-fertilizer inoculation with NP fertilizer increased straw yield by $60.7 \%$ as compared to the control (Table 2). Several workers have reported similar effects of $\mathrm{N}$ fertilizer on total biomass of different crops (Kizilkaya, 2008; Wortman et al., 2011; Scursoni et al., 2012; Getachew et al., 2014) and bio-fertilizer (Saini et al., 2004; Sary et al., 2009; Namvar et al., 2012), Piccinin et al. (2013) also indicated that total biomass of malt barley was improved when malt barley plants were grown with a combination of NP fertilizer and bio-fertilizer inoculation. 
Table 2. The effect of inorganic and growth-promoting microorganisms on grain yield and biomass in Barley (Combined over three years)

\begin{tabular}{|c|c|c|c|}
\hline Treatment & $\mathrm{GY}\left(\mathrm{kg} \mathrm{ha}^{-1}\right)$ & $\mathrm{BY}\left(\mathrm{kg} \mathrm{ha}^{-1}\right)$ & $\mathrm{HI}$ \\
\hline Azotobacter + Pseudomonas $+46 / 20.2 \mathrm{~N} / \mathrm{P} \mathrm{kg} \mathrm{ha}{ }^{-1}$ & $3686.0^{\mathrm{a}}$ & $9388.0^{\mathrm{a}}$ & $40.1^{\mathrm{a}}$ \\
\hline Pseudomonas $+46 / 20.2 \mathrm{~N} / \mathrm{P} \mathrm{kg} \mathrm{ha}^{-1}$ & $3314.0^{b}$ & $9060.0^{\mathrm{a}}$ & $36.9^{a b}$ \\
\hline $46 / 20.2 \mathrm{~N} / \mathrm{P} \mathrm{kg} \mathrm{ha}{ }^{-1}$ & $3104.0^{b c}$ & $8789.0^{\mathrm{ab}}$ & $35.7^{\mathrm{ab}}$ \\
\hline Azotobacter $+46 / 20.2 \mathrm{~N} / \mathrm{P} \mathrm{kg} \mathrm{ha}^{-1}$ & $2862.0^{\mathrm{cd}}$ & $7253.0 \mathrm{bc}$ & $40.5^{a}$ \\
\hline Azotobacter + Pseudomonas & $2555.0^{\mathrm{de}}$ & $7759.0^{a b c}$ & $34.5^{\mathrm{ab}}$ \\
\hline Azotobacter & 2366.0 ef & $6910.0^{\mathrm{cd}}$ & $33.2 \mathrm{~b}$ \\
\hline Pseudomonas & $2162.0 \mathrm{fg}$ & $6255.0^{\mathrm{cd}}$ & $35.0^{\mathrm{ab}}$ \\
\hline$-\mathrm{C}$ (negative control) & $1924.0^{\mathrm{g}}$ & $5469.0^{\mathrm{d}}$ & $35.7^{\mathrm{ab}}$ \\
\hline MEAN & 2746.7 & 7610.4 & 36.8 \\
\hline CV(\%) & 8.2 & 13.6 & 11.4 \\
\hline LSD & 371.4 & 1700.0 & 6.9 \\
\hline
\end{tabular}

Means with different letters are significantly different $(\mathrm{p}<0.05) ; \mathrm{GY}=$ Grain yield, BY =Biomass yield, HI=harvest index.

Table 3. The effect of inorganic and growth-promoting microorganism on yield-related parameters in Barley (Combined over three years)

\begin{tabular}{|c|c|c|c|}
\hline Treatment & $\mathrm{PH}(\mathrm{cm})$ & TSW & NS \\
\hline 1. Azotobacter + Pseudomonas $+46 / 20.2 \mathrm{~N} / \mathrm{P} \mathrm{kg} \mathrm{ha}^{-1}$ & $109.2^{\mathrm{a}}$ & $41.9^{a}$ & $53.1^{\mathrm{c}}$ \\
\hline 2. Pseudomonas $+46 / 20.2 \mathrm{~N} / \mathrm{P} \mathrm{kg} \mathrm{ha}^{-1}$ & $108.3^{\mathrm{a}}$ & $40.4^{a b}$ & $7 \hat{1} .1^{\mathrm{a}}$ \\
\hline 3. $46 / 20.2 \mathrm{~N} / \mathrm{P} \mathrm{kg} \mathrm{ha}^{-1}$ & $107.3^{\mathrm{a}}$ & $40.1^{\mathrm{ab}}$ & $57.4^{a b c}$ \\
\hline 4. Azotobacter $+46 / 20.2 \mathrm{~N} / \mathrm{P} \mathrm{kg} \mathrm{ha}^{-1}$ & $105.6^{\mathrm{a}}$ & $41.6^{\mathrm{a}}$ & $68.7^{\mathrm{ab}}$ \\
\hline 5. Azotobacter + Pseudomonas & $96.7^{\mathrm{b}}$ & $34.1 \mathrm{bc}$ & $65.4^{\mathrm{abc}}$ \\
\hline 6. Azotobacter & $86.9^{\mathrm{c}}$ & $36.4^{\mathrm{abc}}$ & $53.4^{\mathrm{c}}$ \\
\hline 7. Pseudomonas & $84.0^{\mathrm{c}}$ & $32.8^{\mathrm{c}}$ & $63.3^{a b c}$ \\
\hline 8. $-\mathrm{C}$ (negative control) & $80.6^{\mathrm{c}}$ & $35.2^{a b c}$ & $55.3 \mathrm{bc}$ \\
\hline MEAN & 97.3 & 37.8 & 60.9 \\
\hline CV $(\%)$ & 5.4 & 10.9 & 14.9 \\
\hline LSD & 8.6 & 6.8 & 15.2 \\
\hline
\end{tabular}

Means with different letters are significantly different $(\mathrm{p}<0.05) ; \mathrm{PH}=$ plant height, $\mathrm{TSW}=$ thousand seed weight, $\mathrm{NS}=$ number of spikes

\section{CONCLUSIONS}

The results of this study indicated that the combined use of organic and inorganic fertilizers improved yield and yield components of malting barley. The results indicated that the application of Azotobacter and Pseudomonas with chemical fertilizer (nitrogen and phosphorus) has shown a significant influence on yield, and yield components of malt barley. Thus, it seems that inoculating barley with bio-fertilizers (Azotobacter and Pseudomonas) caused the developing root system activity, and increasing plant access ability to nutrients in addition to producing hormones stimulating growth, it also seems that these bio-fertilizers had best and probably synergistic effects on each other which finally led to improving growth traits of barley. So the study results indicated that the application of suitable bio-fertilizers could be efficient in increasing yield, improving growth traits of barley. Thus, we suggested that the combined application of organic and inorganic fertilizers could improve the productivity of malt barley.

\section{ACKNOWLEDGEMENTS}

The authors would like to thank the Ethiopian Institute of Agricultural Research (EIAR) and Kulumsa Agricultural Research Center (KARC) for providing all the necessary facilities and supports during the execution of this study. Our heartfelt thanks also go to the soil microbiology research team of Holetta Agricultural Research Center, Our utmost gratitude to Dr. Asfaw Hailemariam and his team at the National Soil Testing Center for the preparation and provision of Azotobacter biological fertilizers. And we would like to take this opportunity to express our 
immense gratitude for their unreserved efforts from planting to harvesting and proper data management, all members of the Land and Water Resources Research team of Kulumsa Agricultural Research Center are greatly acknowledged.

\section{REFERENCES}

Abedi, T., Alemzadeh, A., Kazemeini, S. A. (2010). Effect of organic and inorganic fertilizers on grain yield and protein banding pattern of wheat. Australian Journal of Crop Science. 4(6): 384-89.

AS, R., Rifat H, Xiao XZ, Nadeem, AA., Safdar, A., Mukhtar ,A., Shakeel ,A. (2019). Exploring Potential Soil Bacteria for Sustainable Wheat (Triticum aestivum L.) Production. sustainability, 11(3361), 1-12. doi:10.3390/su11123361

Ashok, K., \& Vijay, SM., (Eds.). (2019). Plant Growth Promoting Rhizobacteria for Agricultural Sustainability: From Theory to Practices Singapore: Springer.

Daneshmand, N.G., Bakhshandeh, A., Rostami, M.R. (2012). Biofertilizer affects yield and yield. components of wheat. International Journal of Agriculture 2(6): 699-704.

Delelegn, W., \& Fassil, A. (2011). Diversity and Plant Growth Promoting Properties of Rhizobacteria Isolated from tef (Eragrostis tef). Ethiopian Journal of Education And Scence, 6(2), 1-14.

FAOSTAT. (2018). FAOSTAT- Crops/GHDx. Retrieved March 24, 2020, from (http://www.fao.org/faostat/ en/\#data/QC. Retrieved from

Ferede, M., Demsie, Z., \& Tejada, M. (2020). Participatory evaluation of malt barley (Hordium disticum L.) varieties in barley-growing highland areas of Northwestern Ethiopia. Cogent Food \& Agriculture, 6(1). doi:10.1080/23311932.2020.1756142.

Getachew, A., Berhane, L. and Paul, N. (2014). Cropping sequence and nitrogen fertilizer effects on the productivity and quality of malting barley and soil fertility in the Ethiopian highlands. Archives of Agronomy and Soil Science 60, 1261-1275.

Getachew, A., and Tilahun, A. (2017). Integrated Soil Fertility and Plant Nutrient Management in Tropical Agroecocystems: A review. Pedosphere 27(4): 662-680.

Kizilkaya, R. (2008). Yield response and nitrogen concentrations of spring wheat (Triticum aestivum L.) inoculated with Azotobacter chroococcum strains. Ecological Engineering 33(2): 150-156.

Kundu, B.S., Gaur, A.C. (1984). Rice response to inoculation with N2-fixing and P-solubilizing microorganisms. Plant and Soil 74 (227-234).

Liu, D., Shi, Y. (2013). Effects of different nitrogen fertilizer on quality and yield in winter wheat. Advanced Journal of Food Science and Technology 5(5): 646-649.

Mahmoud, M., Hossein, Z., \& Younes , S. (2014). Evaluation of Nano biofertilizer efficiency on Agronomic traits of Spring Wheat at Different sowing Date. Biological Forum - An International Journal, 6(2), 349-356.

MoA (Ministry of Agriculture). (2018). Plant variety release, protection and seed quality control directorate (Crop variety register, Issue No.21). Addis Abeba.

Namvar, A., Khandan, T., Shojaei, M. (2012). Effects of bio and chemical nitrogen fertilizer on grain and oil yield of sunflower (Helianthus annuus L.) under different rates of plant density. Annals of Biological Research 3(2): 1125-1131.

Piccinin, G.G., Braccini, A.L., Dan, L.G.M., Scapim, C.A., Ricci, T.T., Bazo, G. L. (2013). Efficiency of seed inoculation with Azospirillum brasilense on agronomic characteristics and yield of wheat. Industrial Crops and Products 43: 393-397.

Saida, A., Francisco ,JO., Manuel, M., Amin, L., Mohammed, B., \& Abdelhay, A. (2015). Isolation and screening of bacteria from rhizospheric soils of rice fields in Northwestern Morocco for different plant growth promotion (PGP) activities: An in vitro study. International Journal of Current Microbiology And Applied Science. 4(1), 260-269.

Saini, V. K., Bhandari, S. C.,Tarafdar, J. C. (2004). Comparison of crop yield, soil microbial C, N and P, Nfixation, nodulation and mycorrhizal infection in inoculated and non- inoculated sorghum and chickpea crops. Field Crops Research 89: 39-47.

Sary, G. A., El-Naggar, H. M., Kabesh, M.O., E.K., Ramany, M. F., Bakhoum, G.Sh. H. (2009). Effect of bioorganic fertilization and some weed control treatments on yield and yield components of wheat. World Journal of Agricultural Sciences 5(1): 55-62.

SAS. (2009). SAS/STAT 9.2 ® User's Guide (second ed.). Cary, NC, USA: SAS Institute Inc.

Satyanarayana, T., \& Johri, BN.Eds.). (2012). Microorganisms in Sustainable Agriculture and Biotechnology. Netherlands: Springer

Sayyed, R.Z., Reddy, M.S., \& Sarjiya, A. (Eds.). (2019). Plant Growth Promoting Rhizobacteria (PGPR):Prospects for Sustainable Agriculture. Singapore: Springer.

Scursoni, J.A., Palmano, M., De Notta, A., Delfino, D. (2012). Italian ryegrass (Lolium multiflorum Lam.) density and $\mathrm{N}$ fertilization on wheat (Triticum aestivum L.) yield in Argentina. Crop protection 32: 36-40. 
Seyed M., Amin F., Morad S., \& Mohsen, L. (2013). Effect of different biofertilizers on Seed yield of barley (Hurdeom vulgar L.), Bahman cultivar. International journal of Advanced Biological and Biomedical Research, 1(5), 538-546.

Singh, S., Kapoor, K.K. (1992). Solubilization of insoluble phosphates by bacteria and their effect on growth and phosphorus uptake by mung bean. International Journal of Tropical Agriculture 10: 209-213.

Vessey, J. K. (2003). Plant growth promoting rhizobacteria as biofertilizer. Plant and Soil 255: 571-586.

Wortman, S.E., Davis, A.S., Schutte, B.J., Lindquist, J.L. (2011). Integrating management of soil nitrogen and weeds. Weed Science 59: 162-170.

Zorita, M.D., Canigia, M. V. F. (2009). Field performance of a liquid formulation of Azospirillum brasilense on dry land wheat productivity. European Journal of Soil Biology 45(1): 3-11. 